\title{
Genetic associations of ketosis and displaced abomasum with milk production traits in early first lactation of Canadian Holsteins
}

\author{
A. Koeck, ${ }^{* 1}$ F. Miglior,†‡ J. Jamrozik, ${ }^{*}$ D. F. Kelton, $§$ and F. S. Schenkel* \\ ${ }^{*}$ Centre for Genetic Improvement of Livestock, University of Guelph, Guelph, Ontario, Canada, N1G 2W1 \\ †Guelph Food Research Centre, Agriculture and Agri-Food Canada, Guelph, Ontario, Canada, N1G 5C9 \\ ¥Canadian Dairy Network, Guelph, Ontario, Canada, N1K 1 E5 \\ §Department of Population Medicine, Ontario Veterinary College, University of Guelph, Guelph, Ontario, Canada, N1G 2W1
}

\begin{abstract}
The aim of this study was to investigate the genetic associations of ketosis and displaced abomasum with milk production traits in early first lactation of $\mathrm{Ca}$ nadian Holsteins. Health data recorded by producers were available from the national dairy cattle health system in Canada. Test-day records of milk, fat, and protein yields were obtained from the routine milk recoding scheme. Ketosis and displaced abomasum were defined as binary traits $(0=$ healthy; $1=$ sick $)$ based on whether or not the cow had at least 1 case of the respective disease in the period from calving to $100 \mathrm{~d}$ after calving. Mean frequencies of ketosis and displaced abomasum were 4.1 and $2.7 \%$, respectively. The following milk production traits were considered: milk yield, fat percentage (Fat\%), protein percentage (Prot\%), fat-to-protein (F:P) ratio, and $\mathrm{F}: \mathrm{P}$ ratio $>1.5$. The trait F:P ratio $>1.5$ was scored as 1 or 0 , based on whether or not the cow had an F:P ratio $>1.5$. For milk production traits, the first $(5-30 \mathrm{~d}$ in milk) and the second (31-60 d in milk) test days were considered. Data were analyzed using bivariate linear animal models. Average heritabilities of 0.02 and 0.04 were obtained for ketosis and displaced abomasum, respectively. For milk production traits, the lowest heritabilities were obtained for F:P >1.5 (0.04 to 0.08), whereas the highest estimates were found for Prot\% (0.27 to 0.38 ). Ketosis and displaced abomasum were genetically uncorrelated with milk yield in early lactation. Moderate favorable correlations were found between metabolic diseases and milk composition traits. Ketosis was significantly correlated with Fat\% (0.33), F:P ratio (0.30), and F:P ratio $>1.5(0.35)$ at the first test day, whereas all genetic correlations with milk composition traits at the second test day were not significant and close to zero. Significant favorable genetic correlations were also found between displaced abomasum and F:P
\end{abstract}

Received November 22, 2012.

Accepted March 24, 2013.

${ }^{1}$ Corresponding author: akoeck@uoguelph.ca ratio (0.26), F:P ratio $>1.5(0.25)$ and Prot\% $(-0.19)$ at the first test day. Also, Prot\% at the second test day was significantly correlated $(-0.16)$ with displaced abomasum. Overall, a higher Fat\% and F:P ratio and a lower Prot\% at the first test day were associated with an increased susceptibility to metabolic diseases. As genetic correlations between metabolic diseases and F:P ratio were far from unity, dairy producers should be encouraged to keep accurate and complete health data. This will be expected to yield to more accurate genetic evaluations for metabolic diseases.

Key words: ketosis, displaced abomasum, milk production, genetic correlation

\section{INTRODUCTION}

Clinical ketosis and displaced abomasum are the 2 most frequent metabolic diseases in dairy cows. In a literature review, Kelton et al. (1998) found mean disease frequencies of $4.8 \%$ for ketosis and $1.7 \%$ for leftsided displaced abomasum across studies. In a more recent study, Hamann et al. (2004) observed lactation incidence rates of 1.2 and $0.4 \%$ for left- and right-sided displaced abomasum, respectively, in German Holstein cows from the northern part of Lower Saxony. In US Holstein cows, Zwald et al. (2004a) reported disease frequencies of $10 \%$ for ketosis and $3 \%$ for displaced abomasum.

High milk-producing cows were generally found to be genetically more susceptible to ketosis (Lyons et al., 1991; Simianer et al., 1991; Uribe et al., 1995). The relationship between milk production and displaced abomasum is controversial. A slightly favorable relationship between 305-d milk yield and displaced abomasum was observed by Lyons et al. (1991), whereas Uribe et al. (1995) and Hamann et al. (2004) were unable to find a relationship between these traits. In contrast, Ricken et al. (2004) estimated a significant unfavorable genetic correlation of 0.68 between 305-d milk yield and left-sided displaced abomasum. However, analysis of left- and right-sided displaced abomasum as one trait revealed a correlation close to zero. 
In early lactation, high milk-producing cows are phasing high physiological demands and go through various transitional changes (Sordillo et al., 2009). Negative energy balance in early lactation is inevitable and metabolic diseases may follow as a consequence of a severe and prolonged period of negative energy balance (Collard et al. 2000). Energy balance is difficult and expensive to measure in large populations. Therefore, interest exists in other traits, which could be used as indicators of energy balance (Coffey et al., 2001) and may subsequently be related to the metabolic status of an animal. Fat-to-protein $(\mathbf{F}: \mathbf{P})$ ratio has been suggested as an appropriate indicator of energy balance (Buttchereit et al., 2011). A high F:P ratio in early lactation indicates low or negative energy balance, the combined result of elevated fat percentage (Fat\%) and decreased protein percentage (Prot\%). Thus, F:P ratio is negatively correlated with energy balance in early lactation, as shown in a recent study by Buttchereit et al. (2011). They found the highest genetic correlations between $\mathrm{F}: \mathrm{P}$ ratio and energy balance at the beginning of lactation (genetic correlation $=-0.62$ at 15 DIM) and correlations decreased toward zero at the end of the data-recording period at 180 DIM.

Phenotypically, Heuer et al. (1999) observed that the first test-day $\mathrm{F}: \mathrm{P}$ ratio was a risk factor for several diseases, including ketosis and displaced abomasum. Similarly, Toni et al. (2011) reported that cows with an F:P ratio in early postpartum (6-9 DIM) greater than 2.0 showed an increase in postpartum diseases, such as left-displaced abomasum. Estimates of genetic correlations between F:P ratio and metabolic diseases are scarce. Ricken et al. (2004) obtained a genetic correlation of $-0.59 \pm 0.47$ between left-sided displaced abomasum and 305-d F:P ratio. In a recent study by Buttchereit et al. (2012), a genetic correlation of 0.63 \pm 0.91 was found between metabolic diseases and $\mathrm{F}: \mathrm{P}$ ratio in early lactation based on data from a research farm. The authors of the latter study concluded that an improvement of metabolic disease resistance may be achieved if $\mathrm{F}: \mathrm{P}$ ratio is included in dairy cattle breeding programs; however, further research is needed to confirm this promising result.

Studies on genetic relationships between milk production and metabolic diseases are mainly based on 305-d milk production traits. Genetic correlations between metabolic diseases and milk production in early lactation, where most cases of metabolic diseases occur, are practically not available. Furthermore, most studies have been based on data from experimental herds or limited field studies, often including a small number of cows. The small sample size and the lack of power to detect significant associations may account for controversial results found between studies. The objective of the present study was to investigate the genetic associations between metabolic diseases (ketosis and displaced abomasum) and milk production traits in early lactation (milk yield, Fat\%, Prot\%, and F:P ratio) in a large population of Canadian Holsteins. Health data recorded by producers were available from the national dairy cattle health system in Canada. The feasibility of using producer-recorded health data from Canada for genetic evaluations has been shown previously by Koeck et al. (2012) and Neuenschwander et al. (2012).

\section{MATERIALS AND METHODS}

\section{Data}

Health data recorded by dairy producers from April 2007 to August 2012, as well as test-day records of milk, fat, and protein yield, were obtained from the Canadian Dairy Network (Guelph, Ontario, Canada). A summary of the raw and edited data for ketosis and displaced abomasum is given in Table 1. A total of 2,373 and 4,016 herds across Canada recorded cases of ketosis and displaced abomasum, respectively. To ensure that all cows were from herds with reliable health recording, the following editing criteria were applied separately for each disease. Only herds having at least 2 records of the specific disease were considered. The first and last record had to be at least $180 \mathrm{~d}$ distant to remove herds that had done recording just for a short time period. In addition, a minimum disease frequency (reported cases per herd and year) of 1\% was applied for both diseases to ensure continuous data recording within individual herds. After editing, 62 and $52 \%$ of all herds were excluded for the trait ketosis and displaced abomasum, respectively.

Because not all herds that record ketosis also record displaced abomasum and vice versa (Koeck et al., 2012), 2 data sets were created by matching test-day data to ketosis and displaced abomasum records. In both data sets, only records from first-lactation cows with an age between 19 and 43 mo and at least 1 test-day observation in the interval from 5 to 30 DIM were considered. The final data set for ketosis consisted of records from 26,961 first-lactation Holstein cows (daughters of 2,638

Table 1. Summary of the raw and edited data for ketosis and displaced abomasum

\begin{tabular}{lcc}
\hline Item & Ketosis & $\begin{array}{c}\text { Displaced } \\
\text { abomasum }\end{array}$ \\
\hline Total no. of herds & 2,373 & 4,016 \\
Useable herds, \% & 38 & 48 \\
Useable herds, no. & 899 & 1,913 \\
Mean no. of cows per herd & 72 & 72 \\
Mean disease frequency per herd and year, \% & 5.9 & 4.3
\end{tabular}


Table 2. Summary statistics of analyzed data in first-lactation cows

\begin{tabular}{|c|c|c|c|c|c|c|}
\hline Item $^{1}$ & \multicolumn{3}{|c|}{ Data set for ketosis } & \multicolumn{3}{|c|}{ Data set for displaced abomasum } \\
\hline \multicolumn{7}{|l|}{ Disease data } \\
\hline \multicolumn{7}{|c|}{ Milk production data at first test day (5-30 DIM) } \\
\hline Milk yield, kg/d & 26,961 & 28.36 & 6.17 & 63,763 & 28.15 & 6.24 \\
\hline Fat $\%$ & 26,961 & 4.22 & 0.88 & 63,763 & 4.21 & 0.89 \\
\hline \multicolumn{7}{|c|}{ Milk production data at second test day (31-60 DIM) } \\
\hline Milk yield, kg/d & 19,671 & 32.95 & 5.86 & 45,937 & 32.73 & 5.92 \\
\hline Fat $\%$ & 19,671 & 3.63 & 0.55 & 45,937 & 3.63 & 0.56 \\
\hline Prot $\%$ & 19,671 & 2.92 & 0.21 & 45,937 & 2.93 & 0.22 \\
\hline $\mathrm{F}: \mathrm{P}$ ratio & 19,671 & 1.25 & 0.20 & 45,937 & 1.24 & 0.20 \\
\hline $\mathrm{F}: \mathrm{P}$ ratio $>1.5, \%$ & 19,671 & 8.65 & 0.28 & 45,937 & 9.00 & 0.29 \\
\hline
\end{tabular}

${ }^{1}$ Fat $\%=$ fat percentage; Prot $\%=$ protein percentage; $\mathrm{F}: \mathrm{P}$ ratio $=$ fat-to-protein ratio.

sires from 875 herds). The corresponding data set for displaced abomasum included records from 63,763 firstlactation Holstein cows sired by 3,718 different bulls, from 1,868 herds. For each of the 2 data sets, an animal pedigree file was generated by tracing the pedigrees of cows with data 7 generations back.

\section{Trait Definitions}

In Canada, cases of ketosis and displaced abomasum are recorded by producers according to the disease definitions described by Kelton et al. (1998). Primary clinical ketosis is diagnosed if a cow has a decreased appetite and if evidence exists of elevated milk, urine, or breath ketones in the absence of another concurrent disease. Ketosis resulting from another disease (secondary ketosis) will be not recorded. As the majority of cases of displaced abomasum are on the left side (80-90\%; Shaver, 1997), cases of right-sided displaced abomasum are not recorded. Diagnosis of left-sided displaced abomasum is decreased appetite accompanied by an audible, high-pitched tympanic resonance produced by percussion of the left abdominal wall between the 9th and 12th ribs. For analyses, ketosis and displaced abomasum were defined as binary traits $(0=$ healthy; $1=$ sick) based on whether or not the cow had at least 1 case of the respective disease recorded within the first $100 \mathrm{~d}$ after calving.

Test-day records of milk yield, Fat\%, Prot\%, and F:P ratio were considered for each cow. Moreover, a binary variable ( $\mathrm{F}: \mathrm{P}$ ratio $>1.5$ ) was defined as 1 if the cow had an F:P ratio $>1.5$, and 0 otherwise. The threshold of 1.5 was chosen because an F:P ratio greater than 1.5 has previously been shown to be indicative of metabolic diseases (Heuer et al., 1999). For genetic analyses, the first (5-30 DIM) and the second (31-60 DIM) test day were considered. Summary statistics of the analyzed data are given in Table 2.

\section{Models}

Linear animal models were fitted using the average information-restricted maximum likelihood (AI-REML) procedure in the DMU package (Madsen and Jensen, 2008). Although threshold models are, at least in theory, more appropriate to analyze binary traits, linear models were applied. In a previous study on Canadian health data, Neuenschwander (2010) found that the use of threshold models did not improve the goodness of fit compared with linear models. Besides, genetic correlations are reported to be correct for binary traits using linear models (e.g., Negussie et al., 2008).

Bivariate analyses were run between (1) ketosis and milk yield, Fat\%, Prot $\%$, F:P ratio, and F:P ratio $>1.5$ at the first and second test day, and (2) displaced abomasum and milk yield, Fat\%, Prot\%, F:P ratio, and $\mathrm{F}: \mathrm{P}$ ratio $>1.5$ at the first and second test day. The following linear animal model was applied to all traits:

$$
\mathbf{y}=\mathbf{X} \boldsymbol{\beta}+\mathbf{Z}_{\mathbf{h}} \mathbf{h}+\mathbf{Z}_{\mathrm{a}} \mathbf{a}+\mathbf{e},
$$

where $\mathbf{y}$ is a vector of observations; $\boldsymbol{\beta}$ is a vector of systematic effects, including fixed effects of age at calving for all traits, year-season of calving for all traits, and DIM for milk yield, Fat\%, Prot\%, F:P ratio, and F:P ratio $>1.5 ; \mathbf{h}$ is a vector of random herd-year of calving effects for all traits; $\mathbf{a}$ is a vector of random animal additive genetic effects; $\mathbf{e}$ is a vector of random residuals; and $\mathbf{X}, \mathbf{Z}_{\mathrm{h}}$, and $\mathbf{Z}_{\mathrm{a}}$ are the corresponding incidence matrices. Age at first calving had 16 classes, in which $<22$ and $>35$ mo were the first and last class, respectively, and other classes were single months. Four seasons of 
calving were defined; from January to March, April to June, July to September, and October to December. Days in milk was defined in classes, with each day representing a single class.

Random effects were assumed to be normally distributed, with means equals to zero and covariance structure as follows:

$$
\operatorname{Var}\left[\begin{array}{c}
\mathbf{h} \\
\mathbf{a} \\
\mathbf{e}
\end{array}\right]=\left[\begin{array}{ccc}
\mathbf{H}_{0} \otimes \mathbf{I} & 0 & 0 \\
& \mathbf{G}_{0} \otimes \mathbf{A} & 0 \\
\text { symmetric } & \mathbf{R}_{0} \otimes \mathbf{I}
\end{array}\right],
$$

where

$$
\mathbf{H}_{0}=\left[\begin{array}{ll}
\sigma_{h 1}^{2} & \sigma_{h 1 h 2} \\
\sigma_{h 1 h 2} & \sigma_{h 2}^{2}
\end{array}\right]
$$

is the (co)variance matrix between traits due to herdyear ( $h 1$ and $h 2$ ) of calving effects,

$$
\mathbf{G}_{0}=\left[\begin{array}{ll}
\sigma_{a 1}^{2} & \sigma_{a 1 a 2} \\
\sigma_{a 1 a 2} & \sigma_{a 2}^{2}
\end{array}\right]
$$

is the (co)variance matrix between traits due to animal ( $a 1$ and $a 2$ ) additive genetic effects,

$$
\mathbf{R}_{0}=\left[\begin{array}{cc}
\sigma_{e 1}^{2} & \sigma_{e 1 e 2} \\
\sigma_{e 1 e 2} & \sigma_{e 2}^{2}
\end{array}\right]
$$

is the (co)variance matrix between traits due to residual effects ( $e 1$ and $e 2$ ), and $\mathbf{I}$ and $\mathbf{A}$ are identity and additive relationship matrices, respectively.

\section{RESULTS AND DISCUSSION}

\section{Frequencies of Metabolic Diseases}

Figure 1 shows the distribution of metabolic disease cases recorded in each interval. The majority of cases of ketosis (87\%) and displaced abomasum (84\%) occurred during the first $30 \mathrm{~d}$ of lactation. Mean frequencies of ketosis and displaced abomasum were 4.1 and $2.7 \%$, respectively, in first-lactation Holstein cows (Table $2)$. Disease frequencies were generally in the range of previous Canadian studies. In 98 dairy farms located in southern Ontario, Uribe et al. (1995) reported a ketosis frequency of $4.1 \%$ and a displaced abomasum frequency of $2.8 \%$. van Dorp et al. (1999) found much lower incidence rates for ketosis and displaced abomasum ( 0.5 and $0.3 \%$, respectively) based on farm records
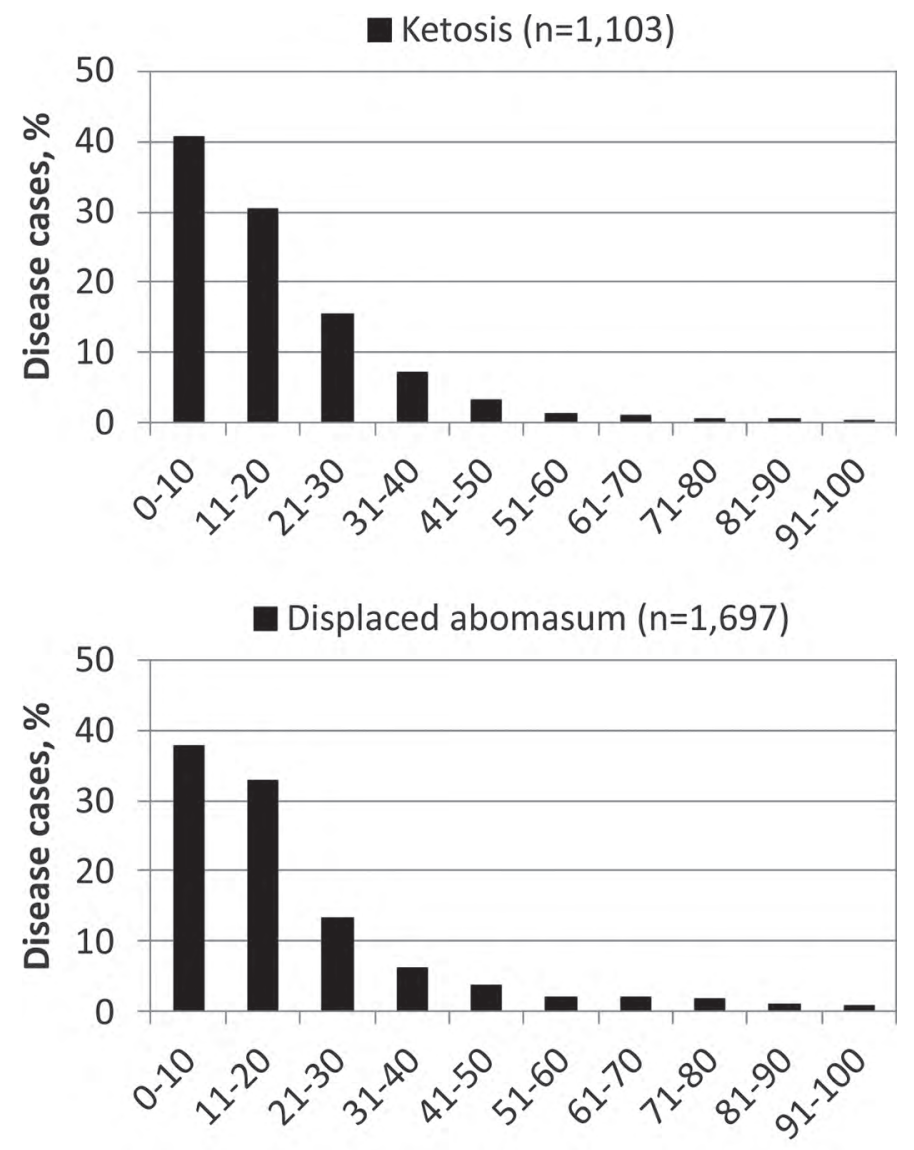

Days after calving

Figure 1. Percentage of disease cases in each interval in first-lactation cows $(\mathrm{n}=$ number of disease cases $)$.

of 32 herds in British Columbia (Canada). In a more recent study conducted in 20 dairy herds in the area of Guelph (Ontario, Canada) the incidence rate of displaced abomasum was estimated to be $5.1 \%$ (LeBlanc et al., 2005).

\section{Phenotypic Associations}

The mean milk yield from healthy and diseased cows throughout lactation is shown in Figure 2. There was a tendency that cows with ketosis had a slightly lower milk yield in early lactation compared with healthy cows, whereas for cows with displaced abomasum, a considerable lower milk yield was observed within the first 3 mo after calving. These findings are confirmed in Figure 3, which shows the mean milk yield of diseased cows from $10 \mathrm{~d}$ before to $30 \mathrm{~d}$ after each disease case. Cows with ketosis had a slight decrease in milk yield during the disease case, whereas cows with displaced abomasum showed a substantial decrease in milk yield. 
a)

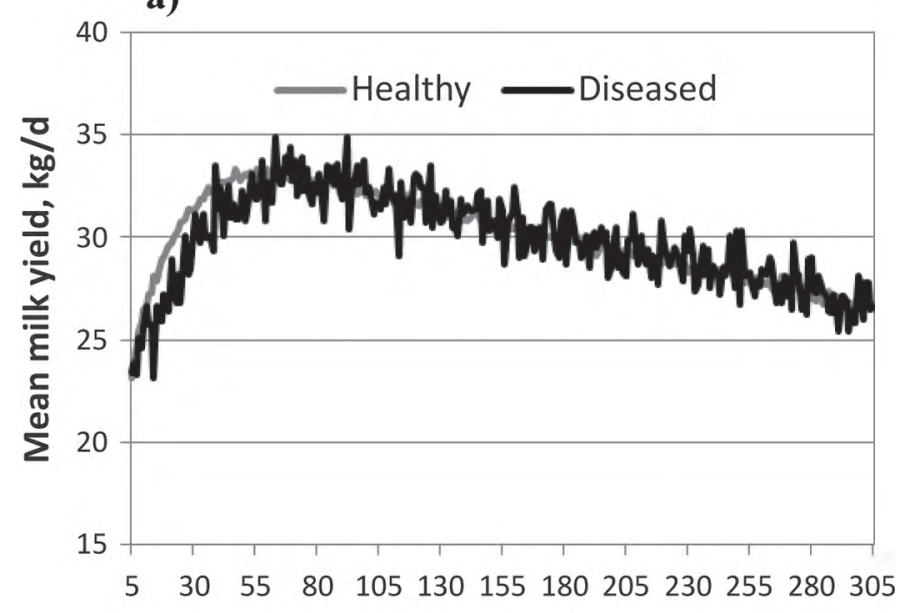

b)

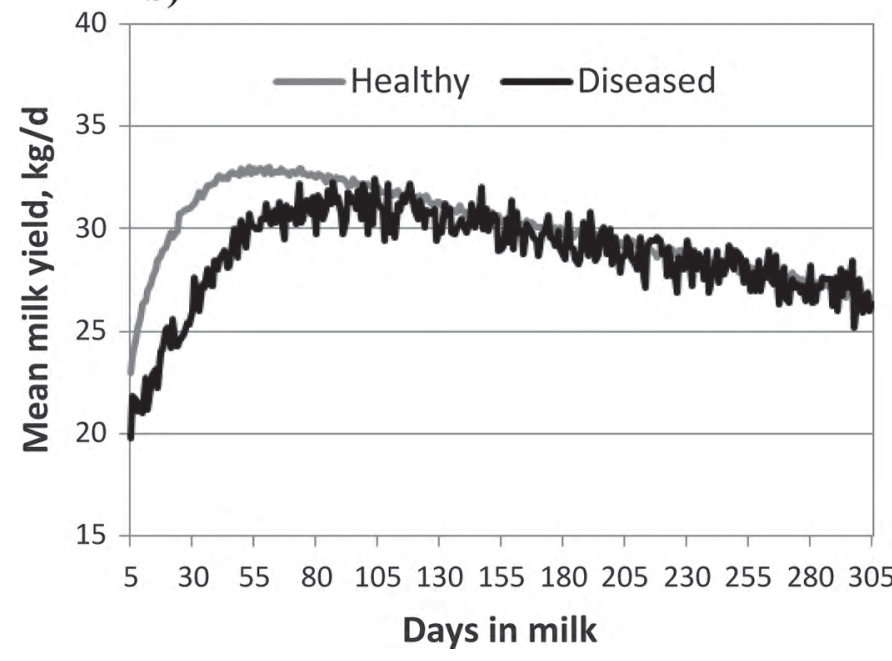

Figure 2. Mean milk yield by DIM in first-lactation cows for (a) healthy and diseased cows with at least 1 case of ketosis within the first $100 \mathrm{~d}$ after calving, and (b) healthy and diseased cows with at least 1 case of displaced abomasum within the first $100 \mathrm{~d}$ after calving.

Figure 4 presents the mean F:P ratio from healthy and diseased cows throughout lactation. In general, the $\mathrm{F}: \mathrm{P}$ ratio was highest at the beginning of lactation between 5 and 100 DIM. Afterward, the F:P ratio stabilized at an average value of around 1.2. In early lactation, the mean F:P ratio from cows with at least 1 case of ketosis or displaced abomasum was higher compared with healthy cows. The mean F:P ratio of diseased cows before the first case of ketosis or displaced abomasum was already at a higher level $(>1.5)$ and decreased after the disease case below the critical value of 1.5 (Figure 5).

Means of analyzed milk production traits at the first and second test day in first-lactation cows with and without ketosis or displaced abomasum are shown in Table 3. At the first test day, cows with ketosis or displaced abomasum had a lower mean milk yield, a higher mean for Fat\%, and a slighter lower mean for Prot\%. As a consequence, the mean F:P ratio and the frequency of $\mathrm{F}: \mathrm{P}$ ratio $>1.5$ were higher in diseased cows. The same trends could be also observed at the second test day; however, differences between healthy and diseased cows were smaller.

\section{Heritabilities}

Average heritability estimates from the bivariate analyses for all traits are given in Tables 4 and 5 . Heritabilities for ketosis and displaced abomasum were 0.02 and 0.04, respectively, which are in agreement with results from previous studies based on linear models. Kadarmideen et al. (2000) obtained a heritability of 0.01 for ketosis. Slightly higher heritability estimates of 0.08 and 0.06 were reported by Dechow et al. (2004)

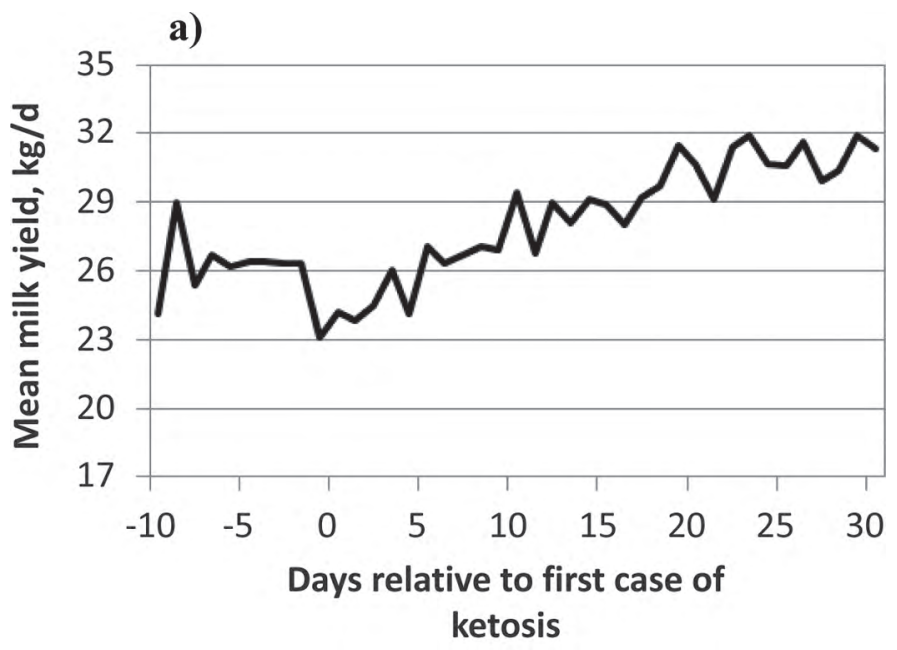

b)

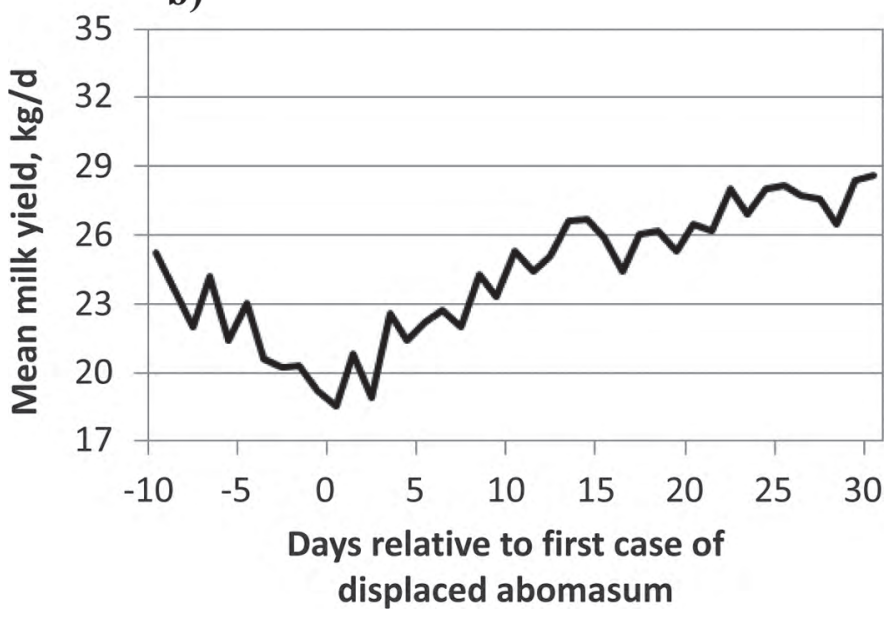

Figure 3. The pattern of mean milk yield in first-lactation cows before and after the first case of (a) ketosis and (b) displaced abomasum. 
Table 3. Mean milk yield, fat percentage (Fat\%), protein percentage (Prot\%), fat-to-protein (F:P) ratio, and frequency of F:P ratio $>1.5$ for cows with absence (0) or presence (1) of ketosis or displaced abomasum in first-lactation cows

\begin{tabular}{lrrrrr}
\hline & \multicolumn{2}{c}{ Ketosis } & & \multicolumn{2}{c}{ Displaced abomasum } \\
\cline { 2 - 3 } \cline { 5 - 6 } Trait & 0 & 1 & & 0 & 1 \\
\hline First test day (5-30 DIM) & 28.44 & 26.56 & & 28.27 & 23.51 \\
Milk yield, kg/d & 4.21 & 4.57 & & 4.20 & 4.69 \\
Fat\% & 3.16 & 3.06 & & 3.16 & 3.06 \\
Prot\% & 1.34 & 1.50 & & 1.34 & 1.54 \\
F:P ratio & 21.62 & 44.97 & & 22.22 & 46.08 \\
F:P ratio >1.5, \% & & & & 32.81 & 29.66 \\
Second test day (31-60 DIM) & 33.00 & 31.80 & & 3.62 & 3.73 \\
Milk yield, kg/d & 3.63 & 3.71 & & 2.93 & 2.86 \\
Fat\% & 2.93 & 2.82 & & 1.24 & 1.31 \\
Prot\% & 1.24 & 1.31 & & 8.86 & 14.40 \\
F:P ratio & 8.32 & 16.67 & & \\
F:P ratio >1.5, \% & & &
\end{tabular}

a)

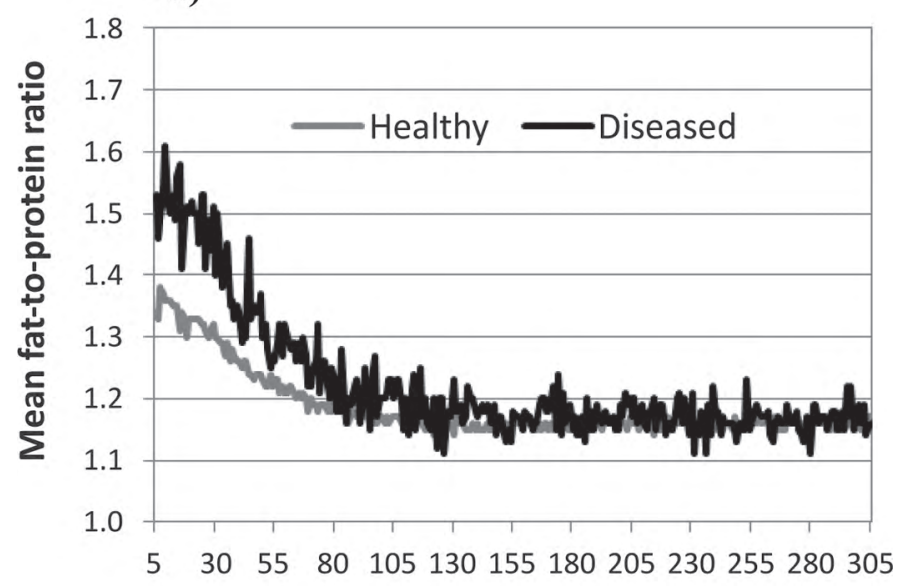

b)

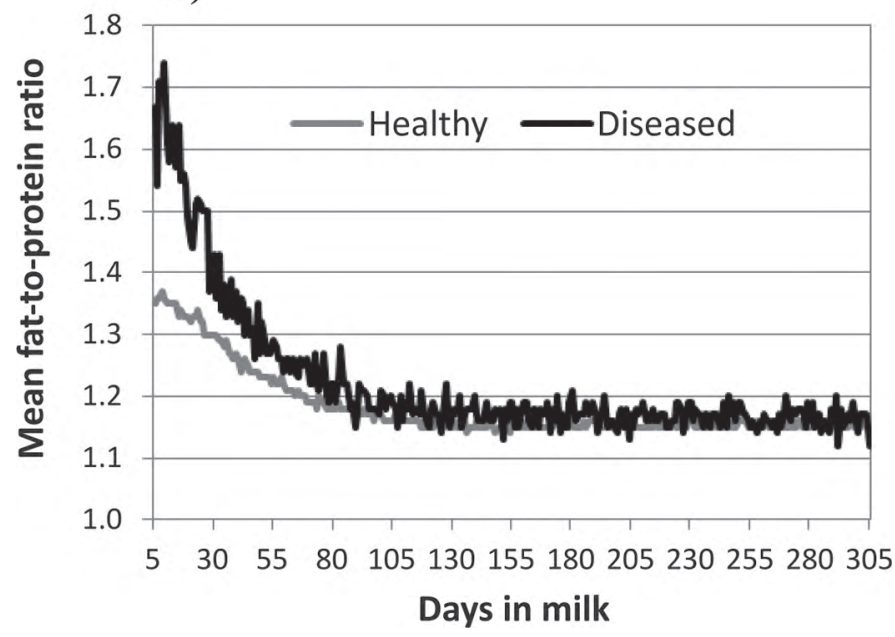

Figure 4. Mean fat-to-protein ratio by DIM in first-lactation cows for (a) healthy and diseased cows with at least 1 case of ketosis within the first $100 \mathrm{~d}$ after calving, and (b) healthy and diseased cows with at least 1 case of displaced abomasum within the first $100 \mathrm{~d}$ after calving.

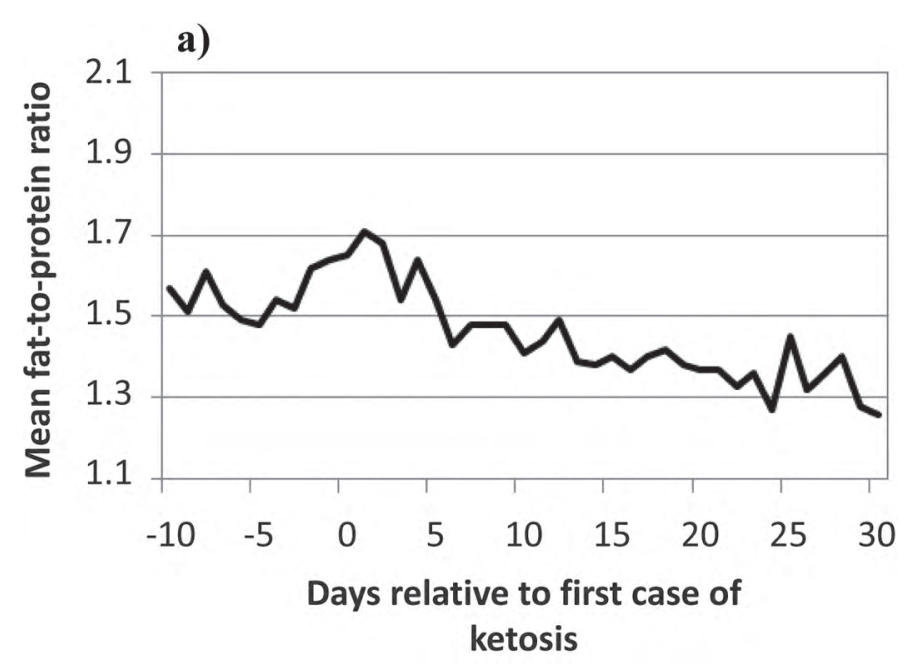

b)

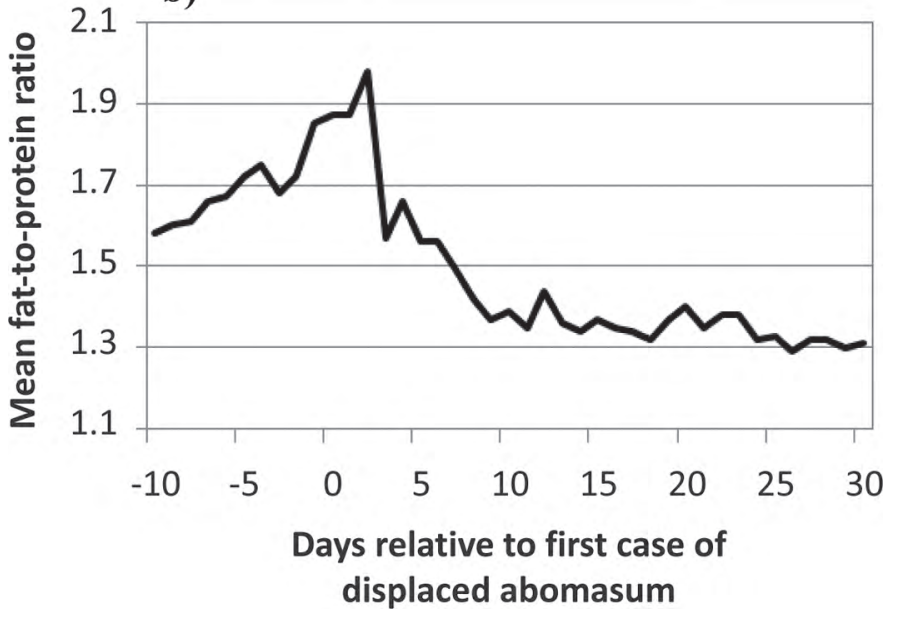

Figure 5. The pattern of mean fat-to-protein ratio in first-lactation cows before and after the first case of (a) ketosis and (b) displaced abomasum. 
Table 4. Estimates of genetic parameters for ketosis, milk yield, fat percentage (Fat\%), protein percentage (Prot\%), fat-to-protein (F:P) ratio, and F:P ratio $>1.5$ in first-lactation cows [heritability ( ${ }^{2}$; SE in parentheses), genetic correlation ( $\mathrm{r}_{\mathrm{g}}$; SE in parentheses), and phenotypic correlation ( $\mathrm{r}_{\mathrm{p}}$; $\mathrm{SE}$ not available)]

\begin{tabular}{|c|c|c|c|}
\hline \multirow[b]{2}{*}{ Trait } & \multirow[b]{2}{*}{$\mathrm{h}^{2}$} & \multicolumn{2}{|c|}{ Ketosis } \\
\hline & & $r_{g}$ & $r_{p}$ \\
\hline Ketosis & $0.02(0.006)^{1}$ & & \\
\hline \multicolumn{4}{|l|}{ First test day (5-30 DIM) } \\
\hline Milk yield & $0.13(0.014)$ & $-0.07(0.15)$ & -0.06 \\
\hline Fat\% & $0.19(0.017)$ & $0.33(0.13)$ & 0.08 \\
\hline Prot $\%$ & $0.27(0.018)$ & $-0.06(0.14)$ & -0.06 \\
\hline $\mathrm{F}: \mathrm{P}$ ratio & $0.15(0.015)$ & $0.30(0.14)$ & 0.12 \\
\hline $\mathrm{F}: \mathrm{P}$ ratio $>1.5$ & $0.07(0.012)$ & $0.35(0.16)$ & 0.11 \\
\hline \multicolumn{4}{|l|}{ Second test day (31-60 DIM) } \\
\hline Milk yield & $0.18(0.017)$ & $0.16(0.15)$ & -0.04 \\
\hline Fat $\%$ & $0.21(0.020)$ & $0.02(0.16)$ & 0.03 \\
\hline Prot $\%$ & $0.35(0.020)$ & $-0.09(0.14)$ & -0.09 \\
\hline $\mathrm{F}: \mathrm{P}$ ratio & $0.14(0.018)$ & $0.05(0.16)$ & 0.07 \\
\hline $\mathrm{F}: \mathrm{P}$ ratio $>1.5$ & $0.03(0.009)$ & $-0.06(0.21)$ & 0.06 \\
\hline
\end{tabular}

${ }^{1}$ Heritability estimate for ketosis was calculated as the average estimate from all bivariate analyses. The corresponding SE was calculated in the same way.

for displaced abomasum and metabolic and digestive diseases, respectively. For left and right-sided displaced abomasum, Hamann et al. (2004) estimated heritabilities of 0.05 and 0.004 , respectively. Also, in a recent study by Mömke et al. (2008) several QTL could be identified for left-sided displaced abomasum.

When transformed to the underlying scale using the classical formula of Dempster and Lerner (1950), the heritabilities of ketosis and displaced abomasum were 0.10 and 0.27 , respectively, and thus, fairly similar to previous estimates based on threshold models (e.g., Zwald et al., 2004a).

Heritability estimates for milk production traits at the first and second test day were almost identical in both data sets. The lowest heritabilities were obtained for $\mathrm{F}: \mathrm{P}$ ratio $>1.5$ (0.04 to 0.08 ), whereas the highest estimates were found for Prot\% (0.27 to 0.38). Based on random regression models, Jamrozik and Schaeffer (2012) obtained similar heritabilities for milk yield and $\mathrm{F}: \mathrm{P}$ ratio in early lactation in first-lactation Canadian Holstein cows.

\section{Genetic and Phenotypic Correlations}

Estimates of genetic correlations between metabolic diseases and milk production traits are shown in Tables 4 and 5. Milk yield at the first and second test day was genetically uncorrelated with both ketosis and displaced abomasum. No previous studies exist on genetic correlations between metabolic diseases and milk production traits in early lactation. Estimates of genetic correlations between 305-d milk yield and ketosis were

Table 5. Estimates of genetic parameters for displaced abomasum, milk yield, fat percentage (Fat\%), protein percentage (Prot\%), fat-to-protein (F:P) ratio, and F:P ratio $>1.5$ in first-lactation cows [heritability $\left(\mathrm{h}^{2}\right.$; SE in parentheses), genetic correlation ( $\mathrm{r}_{\mathrm{g}}$; SE in parentheses), and phenotypic correlation ( $\mathrm{r}_{\mathrm{p}}$; SE not available)]

\begin{tabular}{lcrr}
\hline & & \multicolumn{2}{c}{ Displaced abomasum } \\
\cline { 3 - 4 } Trait & $\mathrm{h}^{2}$ & $\mathrm{r}_{\mathrm{g}}$ & $\mathrm{r}_{\mathrm{p}}$ \\
\hline Displaced abomasum & $0.04(0.005)^{1}$ & & \\
First test day (5-30 DIM) & & & -0.12 \\
Milk yield & $0.14(0.010)$ & $-0.04(0.09)$ & 0.09 \\
Fat\% & $0.19(0.011)$ & $-0.19(0.08)$ & -0.05 \\
Prot\% & $0.28(0.012)$ & $0.26(0.08)$ & 0.12 \\
F:P ratio & $0.16(0.011)$ & $0.25(0.09)$ & 0.09 \\
F:P ratio >1.5 & $0.08(0.008)$ & $0.08(0.09)$ & -0.08 \\
Second test day (31-60 DIM) & & $-0.01(0.09)$ & 0.03 \\
Milk yield & $0.16(0.011)$ & $-0.16(0.08)$ & -0.04 \\
Fat\% & $0.25(0.014)$ & $0.11(0.09)$ & 0.05 \\
Prot\% & $0.38(0.014)$ & $0.09(0.12)$ & 0.03 \\
F:P ratio & $0.17(0.013)$ & $0.04(0.007)$ & \\
F:P ratio >1.5 & &
\end{tabular}

${ }^{1}$ Heritability estimate for displaced abomasum was calculated as the average estimate from all bivariate analyses. The corresponding SE was calculated in the same way. 
found to be mostly unfavorable, with estimates ranging from 0.00 to 0.77 (Mäntysaari et al., 1991; Simianer et al., 1991; Uribe et al., 1995). Ricken et al. (2004) obtained a genetic correlation of 0.68 between $305-\mathrm{d}$ milk yield and left-sided displaced abomasum, which indicates that cows with a higher 305-d milk yield have an increased risk for left-sided displaced abomasum. However, other authors have been unable to verify this finding (Lyons et al., 1991; Uribe et al., 1995; Hamann et al., 2004).

Ketosis was significantly favorably correlated with Fat\% (0.33), F:P ratio (0.30) and $\mathrm{F}: \mathrm{P}$ ratio $>1.5$ $(0.35)$ at the first test day, whereas none of the genetic correlations with milk composition traits at the second test day were significantly different from zero. Similar to the results for ketosis, genetic correlations of displaced abomasum with $\mathrm{F}: \mathrm{P}$ ratio and $\mathrm{F}: \mathrm{P}$ ratio $>1.5$ at the first test day were favorable and moderate (0.26 and 0.25 , respectively). Moreover, a significant negative correlation was found with Prot\% (-0.19). Genetic correlations with milk composition traits at the second test day were mostly not significant; only Prot $\%$ showed a significant correlation with displaced abomasum (-0.16). Overall, a higher Fat\% and F:P ratio and a lower Prot $\%$ at the first test day were associated with an increased susceptibility to metabolic diseases. Milk composition traits at the second test day were mostly uncorrelated with ketosis and displaced abomasum. This was expected, as the majority of cases of ketosis and displaced abomasum occurred during the first $30 \mathrm{~d}$ of lactation (Figure 1). To our knowledge, the genetic relationship of metabolic diseases with F:P ratio in early lactation has been only investigated by Buttchereit et al. (2012) so far, where a moderate genetic correlation of $0.63( \pm 0.91)$ was found in a single research herd.

Phenotypic correlations between metabolic diseases and milk production traits at the first and second test day were generally low. In agreement with the genetic correlations, phenotypic correlations were slightly stronger with milk production traits at the first test day (Tables 4 and 5).

Overall, genetic and phenotypic correlations of milk production traits with ketosis or displaced abomasum were similar in direction and magnitude. As shown in previous studies, ketosis and displaced abomasum are genetically closely linked with each other and share some common genetic background (Zwald et al., 2004b; Neuenschwander et al., 2012).

\section{Final Remarks}

Improving the metabolic stability of dairy cows is an important issue. Of all herds that participate in milk recording ( 9,600; Canadian Dairy Information Centre, 2013), about 25 and $42 \%$ recorded disease cases for ketosis and displaced abomasum, respectively. After data validation about half of these herds remained for further analysis. Therefore, the number of sires with reliable breeding values for metabolic diseases is expected to be low in Canada. This highlights that future work is necessary to increase participation and data quality in the Canadian health-recording system.

In the present study, cases of clinical ketosis were recorded by producers. Diagnosis of ketosis is subjective, as different producers may have different personal thresholds for declaring a cow clinically ketotic. In addition, ketosis occurs both clinically and subclinically. The case definition of subclinical ketosis is an excess level of circulating ketone bodies (acetoacetate, BHBA, and acetone) in the absence of clinical sings of ketosis (Ingvartsen, 2006). As subclinical ketosis occurs much more often than clinical ketosis, with incidences up to $34 \%$ (Ingvartsen, 2006), information about subclinical cases would be useful for genetic evaluation. de Roos et al. (2007) suggested using milk ketone bodies that can be routinely analyzed by Fourier-transform infrared spectroscopy analysis in milk samples at test days for screening cows for subclinical ketosis.

The trait $\mathrm{F}: \mathrm{P}$ ratio has never been considered in dairy cattle breeding programs, although it is routinely recorded and could be obtained at no extra cost. Recently, Jamrozik and Schaeffer (2012) reported favorable genetic associations between SCS and F:P ratio in early lactation in Canadian Holstein cows. In Finnish Ayrshire cows, Negussie et al. (2013) found moderate favorable associations between F:P ratio in early lactation and calving to first insemination, days open, SCS, and clinical mastitis. In the current study, significant favorable associations between F:P ratio in early lactation and metabolic diseases were found. Overall, these results suggest that $\mathrm{F}: \mathrm{P}$ ratio could be used to improve overall robustness of dairy cows in the most critical phase of lactation.

In the current study, only first-lactation cows were included, as the number of first-lactation cows with a second, third, or higher lactation was rather limited. As frequencies of metabolic diseases are higher in later lactations, further studies are needed that also include data from higher lactations.

\section{CONCLUSIONS}

The majority of metabolic disease cases occurred at the beginning of lactation, when physiological demands of the cow are high. Milk yield in early lactation was genetically uncorrelated with ketosis and displaced abomasum, whereas higher $\mathrm{F}: \mathrm{P}$ ratio at the beginning of 
lactation was associated with increased susceptibility to metabolic diseases. As genetic correlations between metabolic diseases and F:P ratio were far from unity, dairy producers should be encouraged to keep accurate and complete health data. This would provide direct information on resistance to metabolic diseases, which would be expected to yield to more accurate genetic evaluations.

\section{ACKNOWLEDGMENTS}

All dairy producers recording health data are gratefully acknowledged. This study was funded by the DairyGen council of the Canadian Dairy Network (Guelph, Ontario, Canada) and the Natural Sciences and Engineering Research Council of Canada (Ottawa, Ontario, Canada).

\section{REFERENCES}

Buttchereit, N., E. Stamer, W. Junge, and G. Thaller. 2011. Short communication: Genetic relationships among daily energy balance, feed intake, body condition score, and fat to protein ratio of milk in dairy cows. J. Dairy Sci. 94:1586-1591.

Buttchereit, N., E. Stamer, W. Junge, and G. Thaller. 2012. Genetic parameters for energy balance, fat/protein ratio, body condition score and disease traits in German Holstein cows. J. Anim. Breed. Genet. 129:280-288.

Canadian Dairy Information Centre. 2013. Enrollments on milk recording. Accessed Jan. 28, 2013. http://www.dairyinfo.gc.ca/index_e. php?s1 $=$ dff-fcil\&s2 $=$ mrr-pcle\&s3 $=$ dhi-agbl\&page $=$ emr-ipcl.

Coffey, M. P., G. C. Emmans, and S. Brotherstone. 2001. Genetic evaluation of dairy bulls for energy balance traits using random regression. Anim. Sci. 73:29-40.

Collard, B. L., P. J. Boettcher, J. C. M. Dekkers, D. Petitclerc, and L. R. Schaeffer. 2000. Relationships between energy balance and health traits of dairy cattle in early lactation. J. Dairy Sci. 83:2683-2690.

de Roos, A. P. W., H. J. C. M. van den Bijgaart, J. Hørlyk, and G. de Jong. 2007. Screening for subclinical ketosis in dairy cattle by Fourier transform infrared spectrometry. J. Dairy Sci. 90:1761-1766.

Dechow, C. D., G. W. Rogers, U. Sander-Nielsen, L. Kiel, T. J. Lawlor, J. S. Clay, A. E. Freeman, G. Abdel-Azim, A. Kuck, and S. Schnell. 2004. Correlations among body conditions scores from various sources, dairy form, and cow health from the United States and Denmark. J. Dairy Sci. 87:3526-3533.

Dempster, E. R., and I. M. Lerner. 1950. Heritability of threshold characters. Genetics 35:212-236.

Hamann, H., V. Wolf, H. Scholz, and O. Distl. 2004. Relationships between lactational incidence of displaced abomasum and milk production traits in German Holstein cows. J. Vet. Med. A Physiol. Pathol. Clin. Med. 51:203-208.

Heuer, C., Y. H. Schukken, and P. Dobbelaar. 1999. Postpartum body condition score and results from the first test day milk as predictors of disease, fertility, yield, and culling in commercial dairy herds. J. Dairy Sci. 82:295-304.

Ingvartsen, K. L. 2006. Feeding- and management-related diseases in the transition cow. Physiological adaptations around calving and strategies to reduce feeding-related diseases. Anim. Feed Sci. Technol. 126:175-213.

Jamrozik, J., and L. R. Schaeffer. 2012. Test-day somatic cell score, fat-to-protein ratio and milk yield as indicator traits for sub-clinical mastitis in dairy cattle. J. Anim. Breed. Genet. 129:11-19.
Kadarmideen, H. N., R. Thompson, and G. Simm. 2000. Linear and threshold model genetic parameters for disease, fertility and milk production in dairy cattle. Anim. Sci. 71:411-419.

Kelton, D. F., K. D. Lissemore, and R. E. Martin. 1998. Recommendations for recording and calculating the incidence of selected clinical diseases of dairy cattle. J. Dairy Sci. 81:2502-2509.

Koeck, A., F. Miglior, D. F. Kelton, and F. S. Schenkel. 2012. Health recording in Canadian Holsteins: Data and genetic parameters. J. Dairy Sci. 95:4099-4108.

LeBlanc, S. J., K. E. Leslie, and T. F. Duffield. 2005. Metabolic predictors of displaced abomasum in dairy cattle. J. Dairy Sci. $88: 159-170$.

Lyons, D. T., A. E. Freeman, and A. L. Kuck. 1991. Genetics of health traits in Holstein cattle. J. Dairy Sci. 74:1092-1100.

Madsen, P., and J. Jensen. 2008. An User's Guide to DMU. A package for analyzing multivariate mixed models. Version 6 , release 4.7. Danish Institute of Agricultural Sciences, Tjele, Denmark.

Mäntysaari, E. A., Y. T. Gröhn, and R. L. Quaas. 1991. Clinical ketosis: Phenotypic and genetic correlations between occurrences and with milk yield. J. Dairy Sci. 74:3985-3993.

Mömke, S., H. Scholz, K. Doll, J. Rehage, and O. Distl. 2008. Mapping quantitative trait loci for left-sided displacement of the abomasum in German Holstein dairy cows. J. Dairy Sci. 91:4383-4392.

Negussie, E., I. Strandén, and E. A. Mäntysaari. 2008. Genetic analysis of liability to clinical mastitis, with somatic cell score and production traits using bivariate threshold-linear and linear-linear models. Livest. Sci. 117:52-59.

Negussie, E., I. Strandén, and E. A. Mäntysaari. 2013. Genetic associations of test-day fat:protein ratio with milk yield, fertility, and udder health traits in Nordic Red cattle. J. Dairy Sci. 96:1237-1250.

Neuenschwander, T. F. O. 2010. Studies on disease resistance based on producer-recorded data in Canadian Holsteins. PhD Thesis. University of Guelph, Guelph, Ontario, Canada.

Neuenschwander, T. F.-O., F. Miglior, J. Jamrozik, O. Berke, D. F Kelton, and L. R. Schaeffer. 2012. Genetic parameters for producer-recorded health data in Canadian Holstein cattle. Animal 6:571-578

Ricken, M., H. Hamann, H. Scholz, and O. Distl. 2004. Genetic analysis of the prevalence of abomasal displacement and its relationship to milk output characteristics in German Holstein cows. Dtsch. Tierärztl. Wochenschr. 111:366-370.

Shaver, R. D. 1997. Nutritional risk factors in the etiology of left displaced abomasum in dairy cows: A review. J. Dairy Sci. 80:24492453

Simianer, H., H. Solbu, and L. R. Schaeffer. 1991. Estimated genetic correlations between disease and yield traits in dairy cattle. J. Dairy Sci. 74:4358-4365.

Sordillo, L. M., G. A. Contreras, and S. L. Aitken. 2009. Metabolic factors affecting the inflammatory response in periparturient dairy cows. Anim. Health Res. Rev. 10:53-63.

Toni, F., L. Vincenti, L. Grigoletto, A. Ricci, and Y. H. Schukken. 2011. Early lactation ratio of fat and protein percentage in milk is associated with health, milk production, and survival. J. Dairy Sci. 94:1772-1783.

Uribe, H. A., B. W. Kennedy, S. W. Martin, and D. F. Kelton. 1995. Genetic parameters for common health disorders of Holstein cows. J. Dairy Sci. 78:421-430.

van Dorp, R. T., S. W. Martin, M. M. Shoukri, J. P. Noordhuizen, and J. C. Dekkers. 1999. An epidemiologic study of disease in 32 registered Holstein dairy herds in British Columbia. Can. J. Vet. Res. 63:185-192.

Zwald, N. R., K. A. Weigel, Y. M. Chang, R. D. Welper, and J. S. Clay. 2004a. Genetic selection for health traits using producerrecorded data. I. Incidence rates, heritability estimates, and sire breeding values. J. Dairy Sci. 87:4287-4294.

Zwald, N. R., K. A. Weigel, Y. M. Chang, R. D. Welper, and J. S. Clay. 2004b. Genetic selection for health traits using producerrecorded data. II. Genetic correlations, disease probabilities, and relationships with existing traits. J. Dairy Sci. 87:4295-4302. 